\title{
Continuous Integrated Process of Biodiesel Production and Purification-The End of the Conventional Two-Stage Batch Process?
}

\author{
Matea Bačić ${ }^{1}$, Anabela Ljubić ${ }^{1}$, Martin Gojun ${ }^{1} \mathbb{D}$, Anita Šalić ${ }^{1, *(\mathbb{D})}$, Ana Jurinjak Tušek ${ }^{2}$ and Bruno Zelić ${ }^{1, *(\mathbb{D})}$ \\ 1 Faculty of Chemical Engineering and Technology, University of Zagreb, Marulićev trg 19, \\ 10000 Zagreb, Croatia; mbacic@fkit.hr (M.B.); aljubic@fkit.hr (A.L.); mgojun@fkit.hr (M.G.) \\ 2 Faculty of Food Technology and Biotechnology, University of Zagreb, Pierottijeva 6, 10000 Zagreb, Croatia; \\ ana.tusek.jurinjak@pbf.unizg.hr \\ * Correspondence: asalic@fkit.hr (A.Š.); bzelic@fkit.hr (B.Z.)
}

Citation: Bačić, M.; Ljubić, A.; Gojun, M.; Šalić, A.; Tušek, A.J.; Zelić, B. Continuous Integrated Process of Biodiesel Production and Purification-The End of the Conventional Two-Stage Batch Process?. Energies 2021, 14, 403. https://doi.org/10.3390/en14020403

Received: 4 December 2020 Accepted: 6 January 2021 Published: 12 January 2021

Publisher's Note: MDPI stays neutral with regard to jurisdictional clai$\mathrm{ms}$ in published maps and institutional affiliations.

Copyright: (C) 2021 by the authors. Licensee MDPI, Basel, Switzerland. This article is an open access article distributed under the terms and conditions of the Creative Commons Attribution (CC BY) license (https:// creativecommons.org/licenses/by/ $4.0 /)$.

\begin{abstract}
In this research, optimization of the integrated biodiesel production process composed of transesterification of edible sunflower oil, catalyzed by commercial lipase, with simultaneous extraction of glycerol from the reaction mixture was performed. Deep eutectic solvents (DESs) were used in this integrated process as the reaction and extraction media. For two systems, choline chloride:glycerol (ChCl:Gly) and choline chloride:ethylene glycol (ChCl:EG), respectively, the optimal water content, mass ratio of the phase containing the mixture of reactants (oil and methanol) with an enzyme and a DES phase (mass ratio of phases), and the molar ratio of deep eutectic solvent constituents were determined using response surface methodology (RSM). Experiments performed with ChCl:Gly resulted in a higher biodiesel yield and higher glycerol extraction efficiency, namely, a mass ratio of phases of $1: 1$, a mass fraction of water of $6.6 \%$, and a molar ratio of the ChCl:Gly of 1:3.5 were determined to be the optimal process conditions. When the reaction was performed in a batch reactor under the optimal conditions, the process resulted in a $43.54 \pm 0.2 \%$ yield and $99.54 \pm 0.19 \%$ glycerol extraction efficiency $(t=2 \mathrm{~h})$. Unfortunately, the free glycerol content was higher than the one defined by international standards $\left(w_{\mathrm{G}}>0.02 \%\right)$; therefore, the process was performed in a microsystem to enhance the mass transfer. Gaining the same yield and free glycerol content below the standards $\left(w_{\mathrm{G}}=0.0019 \pm 0.003 \%\right)$, the microsystem proved to be a good direction for future process optimization.
\end{abstract}

Keywords: biodiesel; lipase; deep eutectic solvent; purification; process optimization

\section{Introduction}

In order to reduce the excessive depletion of fossil fuel stocks and its negative impact on the environment, environmentally friendly alternative fuels are increasingly being explored [1]. Biodiesel, a mixture of fatty acid methyl esters, stands as a suitable replacement for fossil diesel due to its reduced greenhouse gas and impurity emissions compared to fossil diesel combustion [2-5]. The use of biodiesel in a mixture with fossil diesels such as B5, B7, and B20 blends has become common in Europe [6]. Therefore, the production of significant quantities of biodiesel for the lowest possible price is required for its competitiveness on the market [7]. Nowadays, the most common industrial process for biodiesel production is the transesterification of vegetable oils with methanol, carried out in a batch reactor with an alkaline catalyst. Besides the fact that several hours are needed to achieve a sufficient yield in the batch production process, synthetized biodiesel requires additional expensive purification methods to become suitable for application in internal combustion engines $[1,8]$.

Other approaches in biodiesel production include heterogeneous transesterification $[9,10]$ and transesterification under supercritical conditions [11-13], the dilution/ 
blending process [14], microemulsification [15-17], and pyrolysis/cracking [14]. Regardless of the production method, biodiesel must meet some quality standards related to its physical and chemical characteristics. According to the standard EN 14214:2012+A2:2019, the ester content in the biodiesel must be higher than $96.5 \%$ and the glycerol content must be lower than $0.02 \%$ [18]. Since there is an increasing trend towards continuous production instead of batch production, microreactors could be applied for that purpose [19]. Microreactors are commonly tubular reactors in which the efficiency of the reactions can be significantly increased due to their small dimensions (large surface-to-volume ratio). In that way, mass and energy transfer becomes more intense, making the reaction rates much higher in comparison to traditional batch reactors [20]. Furthermore, significant progress can be achieved by using enzymes as transesterification catalysts due to their selectivity, biodegradability, and high activity in a wide range of conditions. In comparison to chemical catalysts, the purity of the product is higher when enzymes are used as catalysts due to the lower amount of by-products formed during the reaction. Furthermore, energy consumption is lower due to the mild reaction conditions that are required during the process [21]. Furthermore, lipase from Thermomyces lanuginosus, an enzyme suitable for transesterification, has commercial significance due to its low price, which makes it affordable compared to other enzymes [22]. All these enzyme-related factors, together with advantages provided by microreactors, could give an environmentally friendly and economically justified biodiesel production process [8]. Production of biodiesel on a microscale is already an established practice [23], but it is mostly oriented towards the use of chemical catalysts [24-27]. Different types of microreactors such as microtube reactors, micro-structured reactors, membrane microreactors, etc., can be used for biodiesel production [1].

The next step in overcoming obstacles in biodiesel production is replacing the most common industrial purification method of wet washing, which generates up to $10 \mathrm{~L}$ of wastewater per $1 \mathrm{~L}$ of produced biodiesel $[1,8]$. Taking into consideration that $60-80 \%$ of the production costs belongs to the purification steps, it can be concluded that a cheaper and more efficient solution needs to be found [28]. Lately, deep eutectic solvents (DESs) are attracting more and more attention as a potential solution for biodiesel purification [29]. A DES is a binary or ternary mixture consisting of a hydrogen bond donor (HBD) and a hydrogen bond acceptor (HBA), which forms a hydrogen bond [30]. Their advantages include cheap constitutive components such as choline chloride as an HBA representative and naturally derived HBDs such as various sugars, alcohols, and amides [31]. The production of DESs is very simple and cheap. It is possible to easily adjust their properties by changing the constitutive components of DESs and their ratios [32]. Furthermore, DESs are especially attractive because of their stability, biodegradability, non-toxicity, and low volatility, thus fitting into the concept of green chemistry as green solvents [31].

DESs composed of choline chloride as the HBA and ethylene-glycol or glycerol as HBDs are most commonly used for biodiesel purification. These DESs effectively remove not only glycerol, which is the most challenging impurity in biodiesel, but also other unwanted compounds such as unreacted products and catalysts [33]. Furthermore, DESs are increasingly being investigated in the context of their use as reaction media, especially in biocatalysis, because some studies have shown that lipases have high activity and stability in DESs in the presence of a certain percentage of water [3,31,34]. Since the simultaneous use of DESs as reaction and extraction media is still unexplored, it is necessary to optimize such an integrated process [6]. An optimization method that is very popular among researchers is response surface methodology (RSM) [35]. RSM is based on determining the functional dependence of the process response on independent variables that affect the response by mathematical and statistical techniques. In addition, based on the obtained experimental data, a mathematical model of the process is generated, which is used for numerical optimization of the process [36,37].

In this paper, the optimization of the transesterification process with integrated purification - glycerol extraction from produced biodiesel — was performed. Edible sun- 
flower oil and methanol were used as substrates and the commercial enzyme lipase from Thermomyces lanuginosus was used as a catalyst in transesterification, while a DES was used as the reaction medium and as an extraction medium for biodiesel purification. Two DESs were used for integrated production and purification of biodiesel: choline chloride with glycerol (ChCl:Gly) as an HBD and choline chloride with ethylene glycol (ChCl:EG) as an HBD. RSM was applied to optimize the process conditions where biodiesel yield was an objective function. For the two systems that differed in the DES used, the optimal values of the mass ratio of the phase containing a mixture of reactants (oil and methanol) with an enzyme and a DES phase (mass ratio of phases), water content, as well as the molar ratio of the DES constituents were determined by numerical optimization. Finally, the integrated biodiesel production and purification process was carried out under optimal conditions in a batch reactor and in a microreactor.

\section{Materials and Methods}

\subsection{Materials}

Chemicals

The following chemicals were used to perform the experiment. Acetylacetone, acetonitrile, $n$-hexane, $n$-heptane, hydrochloric acid, methanol, sodium periodate, and tris (hydroxymethyl)aminometal (TRIS) were produced by VWR Chemicals, BDH Prolabo (Lutterworth, United Kingdom). Edible sunflower oil (Zvijezda, Zagreb, Croatia) was purchased at a local store. Enzyme lipase from Thermomyces lanuginosus (Lipolase $100 \mathrm{~L}$ ) and a fatty acid methyl ester (FAME) mix GLC-10 were purchased from Sigma-Aldrich Handels GmBH (Vienna, Austria). Glycerol was purchased from Kemika (Zagreb, Croatia) and ethanol from Gram mol d.o.o. (Zagreb, Croatia). Choline chloride and 4-nitrophenyl acetate were purchased from Acros Organics (Geel, Belgium), the ethylene glycol was purchased from Lach-Ner (Prague, Czech Republic), and acetic acid from Carlo Erba Reagents (Sabadell, Spain). With the exception of sunflower oil, chemicals and reagents were of analytical grade and were used without any further purification.

\subsection{Methods}

\subsubsection{Preparation of Deep Eutectic Solvents (DESs)}

Choline chloride $(\mathrm{ChCl})$ and glycerol (Gly), and choline chloride and ethylene glycol (EG) in different molar ratios were used to prepare anhydrous $\mathrm{ChCl}$ :Gly and $\mathrm{ChCl}$ :EG DESs, respectively (Table 1). After weighing each component according to the desired molar ratio, the components were placed in a Schott bottle $(V=50 \mathrm{~mL})$ and mixed on a magnetic stirrer (MS-H-S, DLAB, Ontario, CA, USA) at $200 \mathrm{rpm}$ and $50^{\circ} \mathrm{C}$. The process was carried out for 30-60 min until a homogeneous, colorless, transparent liquid was obtained. DESs were then cooled to $25^{\circ} \mathrm{C}$.

Table 1. The molar ratios of choline chloride:glycerol (ChCl:Gly) and choline chloride:ethylene glycol (ChCl:EG) used for the preparation of deep eutectic solvents (DESs).

\begin{tabular}{|c|c|c|}
\hline \multirow{2}{*}{$\begin{array}{c}\text { Molar Ratio } \\
1: 2\end{array}$} & \multicolumn{2}{|c|}{ Prepared DES } \\
\hline & ChCl:Gly $1: 2$ & $\mathrm{ChCl:EG}$ \\
\hline $1: 3$ & ChCl:Gly & $\mathrm{ChCl:EG} 1: 3$ \\
\hline $1: 3.5$ & ChCl:Gly $1: 3.5$ & - \\
\hline $1: 4$ & ChCl:Gly:4 & $\mathrm{ChCl:EG} 1: 4$ \\
\hline
\end{tabular}

\subsubsection{Optimization of Integrated Biodiesel Production and Purification Processes}

In order to optimize the integrated process composed of simultaneous biodiesel production (by transesterification) and purification (glycerol extraction), experiments were carried out according to the experimental plan (Table 2), changing the mass ratio of a reaction phase (oil, methanol, enzyme, and water) and the DES phase, water content, and molar ratios of DES constituents (Table 2). The required masses of oil and methanol were weighed into conical centrifuge tubes $(V=15 \mathrm{~mL})$, with their molar ratio always being 1:3.4 [38]. 
The content of the centrifuge tubes was well homogenized on a homogenizer (Vibromix 10, Tehtnica, Železniki, Slovenia) and the appropriate amount of DESs was added into the centrifuge tube. The content of the centrifuge tubes was well homogenized, followed by the addition of water and lipase according to the experimental plan (Table 2). The initial concentration of lipase was equal in all performed experiments $\left(\gamma_{\mathrm{E}, 0}=0.1 \mathrm{mg} \mathrm{mL}^{-1}\right)$. After homogenization, the centrifuge tubes were attached to a rack and placed in a shaker (Innova 4330 Refrigerated Incubator Shaker, New Brunswick Scientific, Enfield, CT, USA) for $2 \mathrm{~h}$ at $400 \mathrm{rpm}$ and at a temperature of $40^{\circ} \mathrm{C}$. After incubation, the centrifuge tubes were removed and immediately centrifuged (Universal 320 R, Hettich, Buford, GA, USA) for $10 \mathrm{~min}$ at $4000 \mathrm{rpm}$ and at $40^{\circ} \mathrm{C}$. As a result, two clearly visible layers were formed. Layer volumes were measured and the top layer containing mainly biodiesel was centrifuged again for $10 \mathrm{~min}$ at $14,000 \mathrm{rpm}$ and at $40{ }^{\circ} \mathrm{C}$ in order to completely precipitate the DES that may have remained during the first centrifugation. Biodiesel samples obtained in this manner were analyzed by gas chromatography and on a spectrophotometer. Based on the measured concentrations of biodiesel and glycerol in the samples, the yield of biodiesel $(Y)$, the extraction efficiency of glycerol $(\eta)$, and the mass fraction of glycerol in biodiesel $\left(w_{\mathrm{G}}\right)$ were calculated.

Table 2. Experimental design and analyzed responses for investigated DESs.

\begin{tabular}{|c|c|c|c|c|c|c|c|c|c|}
\hline \multirow{3}{*}{ Run } & \multicolumn{3}{|c|}{ Experimental Design } & \multicolumn{6}{|c|}{ Analyzed Responses } \\
\hline & \multirow{2}{*}{$\begin{array}{l}w_{\text {water }} \\
\% \text { Mass }\end{array}$} & \multirow{2}{*}{$\begin{array}{l}\text { ChCl:Gly or } \\
\text { ChCl:EG (1:X) }\end{array}$} & \multirow{2}{*}{$\begin{array}{c}\text { Mass Ratio } \\
\text { of Phases }\end{array}$} & \multicolumn{3}{|c|}{ ChCl:Gly } & \multicolumn{3}{|c|}{ ChCl:EG } \\
\hline & & & & $Y, \%$ & $\eta, \%$ & $w_{\mathrm{G}}, \%$ & $Y, \%$ & $\eta, \%$ & $w_{\mathrm{G}}, \%$ \\
\hline 1 & $0.6(-1)$ & $2.0(-1)$ & 1:1 (0) & $6.96 \pm 0.21$ & $86.36 \pm 0.40$ & $0.129 \pm 0.01$ & $1.15 \pm 0.11$ & $58.65 \pm 2.84$ & $0.065 \pm 0.02$ \\
\hline 2 & $8.6(1)$ & $2.0(-1)$ & 1:1(0) & $40.82 \pm 0.66$ & $86.92 \pm 0.15$ & $5.629 \pm 1.02$ & $12.15 \pm 0.64$ & $33.52 \pm 2.54$ & $1.098 \pm 0.30$ \\
\hline 3 & $0.6(-1)$ & $4.0(1)$ & 1:1 (0) & $14.31 \pm 0.35$ & $89.97 \pm 0.18$ & $0.195 \pm 0.22$ & $1.18 \pm 0.07$ & $40.66 \pm 2.69$ & $0.095 \pm 0.04$ \\
\hline 4 & $8.6(1)$ & $4.0(1)$ & 1:1 (0) & $44.55 \pm 1.16$ & $91.63 \pm 0.16$ & $0.507 \pm 0.07$ & $13.05 \pm 0.40$ & $95.93 \pm 0.09$ & $0.072 \pm 0.03$ \\
\hline 5 & $0.6(-1)$ & $3.0(0)$ & 1:9 (1) & $21.12 \pm 0.15$ & $98.54 \pm 0.01$ & $0.042 \pm 0.02$ & $0.35 \pm 0.08$ & $55.39 \pm 0.14$ & $0.021 \pm 0.01$ \\
\hline 6 & $8.6(1)$ & $3.0(0)$ & 1:9 (1) & $30.37 \pm 0.23$ & $54.13 \pm 0.26$ & $1.894 \pm 0.36$ & $4.04 \pm 0.19$ & $64.47 \pm 6.05$ & $0.195 \pm 0.09$ \\
\hline 7 & $0.6(-1)$ & $3.0(0)$ & $9: 1(-1)$ & $3.82 \pm 0.54$ & $81.06 \pm 1.95$ & $0.098 \pm 0.02$ & $1.90 \pm 0.21$ & $67.97 \pm 0.01$ & $0.083 \pm 0.05$ \\
\hline 8 & $8.6(1)$ & $3.0(0)$ & $9: 1(-1)$ & $33.40 \pm 0.27$ & $98.82 \pm 0.01$ & $0.054 \pm 0.01$ & $30.38 \pm 0.27$ & $95.04 \pm 0.09$ & $0.205 \pm 0.10$ \\
\hline 9 & $4.6(0)$ & $2.0(-1)$ & $1: 9(1)$ & $33.42 \pm 1.36$ & $99.29 \pm 0.02$ & $0.032 \pm 0.05$ & $3.55 \pm 0.32$ & $57.37 \pm 1.23$ & $0.206 \pm 0.07$ \\
\hline 10 & $4.6(0)$ & $4.0(1)$ & $1: 9(1)$ & $29.40 \pm 0.52$ & $99.02 \pm 0.01$ & $0.039 \pm 0.01$ & $3.56 \pm 0.98$ & $92.15 \pm 0.06$ & $0.038 \pm 0.01$ \\
\hline 11 & $4.6(0)$ & $2.0(-1)$ & $9: 1(-1)$ & $25.18 \pm 0.32$ & $99.80 \pm 0.02$ & $0.007 \pm 0.01$ & $9.87 \pm 0.26$ & $55.19 \pm 7.68$ & $0.601 \pm 0.15$ \\
\hline 12 & $4.6(0)$ & $4.0(1)$ & $9: 1(-1)$ & $28.80 \pm 0.07$ & $98.73 \pm 0.00$ & $0.050 \pm 0.03$ & $13.92 \pm 2.16$ & $96.03 \pm 0.29$ & $0.075 \pm 0.01$ \\
\hline 13 & $4.6(0)$ & $3.0(0)$ & $1: 1(0)$ & $45.41 \pm 1.29$ & $94.47 \pm 0.74$ & $0.341 \pm 0.27$ & $9.02 \pm 0.23$ & $41.68 \pm 0.58$ & $0.715 \pm 0.43$ \\
\hline 14 & $4.6(0)$ & $3.0(0)$ & 1:1(0) & $40.59 \pm 0.13$ & $87.56 \pm 0.29$ & $0.687 \pm 0.14$ & $4.79 \pm 0.55$ & $39.13 \pm 3.39$ & $0.396 \pm 0.21$ \\
\hline 15 & $4.6(0)$ & $3.0(0)$ & 1:1(0) & $45.11 \pm 2.16$ & $91.94 \pm 0.28$ & $0.495 \pm 0.21$ & $7.00 \pm 0.35$ & $89.65 \pm 4.13$ & $0.099 \pm 0.02$ \\
\hline
\end{tabular}

\subsubsection{Integrated Biodiesel Production and Purification in a Batch Reactor}

The integrated biodiesel production and purification process was carried out in a laboratory double wall batch reactor $\left(V=10 \mathrm{~mL}, t=2 \mathrm{~h}, 400 \mathrm{rpm}\right.$, and $T=40^{\circ} \mathrm{C}$; Figure 1). Three different compositions of reaction media were used. In Experiment I, the synthesis of biodiesel was performed in an aqueous medium $\left(0.01 \mathrm{~mol} \mathrm{~L}^{-1}\right.$ phosphate buffer, $\mathrm{pH} 7.4$, water content of $4.6 \% w / w$ ) without DES addition. Experiment II was performed with DES addition at initial conditions used as the central point of the experimental plan (mass ratio of phases 1:1, mass fraction of water of 4.6\%, and molar ratio of DES constituents of 1:3; Table 2), while Experiment III was performed at optimized conditions (mass ratio of phases ratio 1:1, mass fraction of water of $6.6 \%$, and molar ratio of DES constituents of 1:3.5). All experiments were performed at the same molar ratio of oil and methanol (1:3.4) and at equal initial lipase concentrations $\left(\gamma_{\mathrm{E}, 0}=0.1 \mathrm{mg} \mathrm{mL}^{-1}\right)$ as in the experiments performed for optimization purposes. 


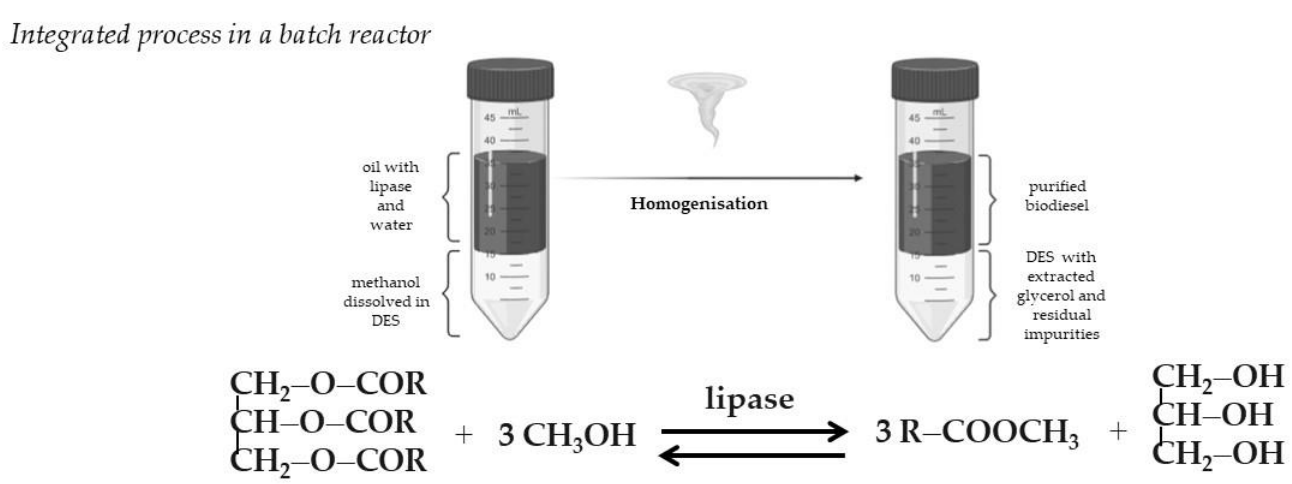

Integrated process in a microreactor

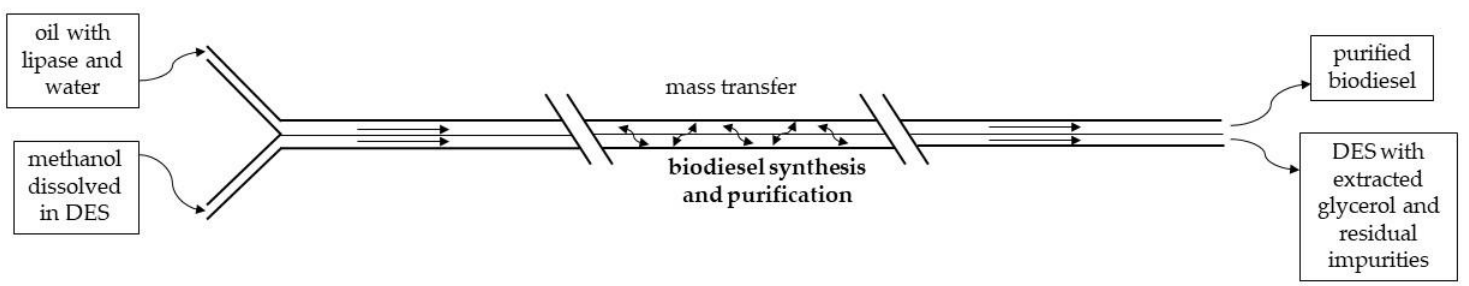

Figure 1. Schematic diagram of the integrated biodiesel production and purification in a batch reactor and in a microsystem.

\subsubsection{Integrated Biodiesel Production and Purification Process in a Microsystem}

The integrated biodiesel production and purification process was performed in a microsystem to investigate any potential enhancements of the process (Figure 1). The synthesis of biodiesel was carried out in a polytetrafluoroethylene (PTFE) tubular microreactor (length:diameter $=1.2 \mathrm{~m}: 500 \mu \mathrm{m}$, with a total volume of $236 \mu \mathrm{L}$ ). The PTFE microreactor was equipped with a Y-shaped input. Two piston pumps (Harvard Apparatus, Holliston, MA, USA) were connected to the microreactor by PTFE tubes, with the first pump supplying oil mixed with lipase, while methanol mixed with a DES was fed with the second pump. The oil to methanol ratio (1:3.4) and enzyme concentration in the inlet stream $\left(\gamma_{\mathrm{E}, 0}=0.1 \mathrm{mg} \mathrm{mL}^{-1}\right)$ were kept constant as in the batch processes. A microreactor was placed in a water bath heated to $40{ }^{\circ} \mathrm{C}$ to carry out the process at the optimum temperature for transesterification. The total flow was $1.96 \mu \mathrm{L} \mathrm{min}^{-1}(\tau=120 \mathrm{~min})$.

\subsubsection{Influence of Temperature on the Efficiency of Glycerol Extraction}

In order to investigate the influence of temperature on the extraction efficiency, batch experiments were performed at $40^{\circ} \mathrm{C}, 50^{\circ} \mathrm{C}$, and $60^{\circ} \mathrm{C}$. The integrated production and biodiesel purification process was carried out in a glass batch reactor with double walls $(V=10 \mathrm{~mL}$ ). Appropriate weights of oil and methanol (molar ratio 1:3.4) were added in the eutectic solvent, while the reaction was started with the addition of an aqueous lipase suspension. The initial concentration of the enzyme in the reaction mixture was $\gamma_{\mathrm{E}, 0}=0.1 \mathrm{mg} \mathrm{mL}^{-1}$. The reactor was placed on a magnetic stirrer, and the reaction mixture was stirred at $400 \mathrm{rpm}$ for $48 \mathrm{~h}$. Afterwards, the reaction mixture was transferred to a separation funnel to separate the biodiesel phase from the deep eutectic solvent phase. The sample of the biodiesel phase was analyzed by gas chromatography.

2.2.6. Measurement of the Concentration of Fatty Acid Methyl Esters and Glycerol by Gas Chromatography

The concentration of fatty acid methyl esters (FAMEs) and glycerol was determined on a gas chromatograph equipped with a flame ionization detector (FID detector) and a Zebron ZB-Wax GC capillary column (length: $30 \mathrm{~m}$; internal diameter: $0.53 \mathrm{~mm}$; film thickness: $1.00 \mu \mathrm{m})$. Concentrations of FAME and glycerol were determined as described elsewhere [38]. For $1 \mathrm{~min}$, the column was heated starting at a temperature of $180^{\circ} \mathrm{C}$, with heating to $230{ }^{\circ} \mathrm{C}$ at the rate of $5{ }^{\circ} \mathrm{C} \mathrm{min}-1$, while the FID detector operated at $240{ }^{\circ} \mathrm{C}$. 
According to the method, the total duration of analysis for each sample was $15 \mathrm{~min}$, and nitrogen with a flow rate of $1.97 \mathrm{~mL} \mathrm{~min}^{-1}$ was used as the carrier gas. A mixture of the FAME mix GLC-10 was used as a standard to identify the corresponding fatty acid esters. The sample for analysis was diluted 100-fold to obtain concentrations in the area covered by the calibration diagram. $N$-heptane was used as the solvent for sample preparation to determine the concentration of FAME, while ethanol was used as the solvent for sample preparation in the analysis of glycerol. After homogenization, the sample was filtered and analyzed. The retention times for the individual components were as follows: $7.74 \mathrm{~min}$ for palmitic, $10.59 \mathrm{~min}$ for stearin, $10.87 \mathrm{~min}$ for oleic, $11.58 \mathrm{~min}$ for linoleic, and $12.62 \mathrm{~min}$ for $\alpha$-linolenic (linolenic) esters. The retention time for glycerol was $9.02 \mathrm{~min}$, using the same method. To determine repeatability, all measurements were performed in triplicate.

\subsubsection{Spectrophotometric Measurement of Glycerol Concentration}

The concentration of glycerol in the sample was determined as described by Bondioli and Della Bella [39]. Briefly, $0.5 \mathrm{~g}$ of the biodiesel sample $( \pm 0.1 \mathrm{mg})$ was weighed into a 10-mL conical centrifuge tube. The sample was then dissolved in $2 \mathrm{~mL}$ hexane and $2 \mathrm{~mL}$ working solvent was added. The resulting mixture was then homogenized for $5 \mathrm{~min}$ and centrifuged for $15 \mathrm{~min}$ at $2000 \mathrm{rpm}$ and $25^{\circ} \mathrm{C}$. After centrifugation, the upper layer (biodiesel) was removed and $0.5 \mathrm{~mL}$ of the lower layer was transferred to a $10-\mathrm{mL}$ conical centrifuge tube. In this sample, $1.5 \mathrm{~mL}$ of working solvent (equal volumes of distilled water and $95 \%$ ethanol) and $1.2 \mathrm{~mL}$ sodium periodate solution were added. The resulting sample was homogenized for $30 \mathrm{~s}$, followed by the addition of $1.2 \mathrm{~mL}$ of $0.2 \mathrm{~mol} \mathrm{~L}^{-1}$ acetylacetone solution. The conical centrifuge tubes were placed in a pre-thermostated water bath (Thermomix 1420, Braun, Melsungen, Germany) at $70^{\circ} \mathrm{C}$ for $1 \mathrm{~min}$, with manual stirring. After thermostating at $70^{\circ} \mathrm{C}$, the sample was transferred to a water bath at $20^{\circ} \mathrm{C}$ for $2 \mathrm{~min}$ with manual stirring. The samples were then centrifuged at $2000 \mathrm{rpm}$ and $25^{\circ} \mathrm{C}$ for $1 \mathrm{~min}$. Thus, $1 \mathrm{~mL}$ of the sample was obtained and transferred to plastic cuvettes and analyzed spectrophotometrically (UV-1601, Shimadzu, Kyoto, Japan) at a wavelength of $\lambda=410 \mathrm{~nm}$. To determine repeatability, all measurements were performed in triplicate and the glycerol concentration was calculated based on the calibration curve.

\subsubsection{Measurement of Lipase Activity}

The measurement of lipase activity was based on the solvolysis of $0.0375 \mathrm{~mol} \mathrm{~L}^{-1}$ of 4-nitrophenyl acetate. Briefly, $100 \mu \mathrm{L}$ of sample was added to $3900 \mu \mathrm{L}$ of $0.05 \mathrm{~mol} \mathrm{~L}^{-1}$ Tris- $\mathrm{HCl}$ buffer, $\mathrm{pH} 8$, and homogenized. After homogenization, $950 \mu \mathrm{L}$ of the mixture was transferred to a UV cuvette previously thermostated at $40{ }^{\circ} \mathrm{C}$ in a water bath. The reaction was started by adding $50 \mu \mathrm{L}$ of $0.0375 \mathrm{~mol} \mathrm{~L}^{-1}$ of 4-nitrophenyl acetate previously dissolved in acetonitrile. The enzyme activity was determined spectrophotometrically (UV-1800, Shimadzu, Kyoto, Japan) by measuring the change in absorbance at the wavelength of $\lambda=400 \mathrm{~nm}$, with a total determination time of $20 \mathrm{~s}$. To determine repeatability, all measurements were performed in triplicate.

\subsubsection{Optimization of the Extraction Process by Response Surface Methodology (RSM)}

Impacts of the three separate variables (water content $\left(X_{1}\right)$, DES composition $\left(X_{2}\right)$, and mass ratio of phases $\left(X_{3}\right)$ ) on the biodiesel yield $(Y)$ were assessed by applying the Box-Behnken design implemented in Statistica version 10.0 (StatSoft Inc., Tulsa, OK, USA). The impact of independent variables was investigated at three levels $(-1,0$, and 1$)$ through 15 experiments according to the experimental design. The parameters of the second-order polynomial model were estimated to describe the experimental data (Equation (1), [40])

$$
Y=\beta_{0}+\sum_{\mathrm{i}=1}^{3} \beta_{\mathrm{i}} \cdot X_{\mathrm{i}}+\sum_{\mathrm{i}=1}^{3} \beta_{\mathrm{ii}} \cdot X_{\mathrm{i}}^{2}+\sum_{\mathrm{i}=1}^{2} \sum_{\mathrm{j}=\mathrm{i}+1}^{3} \beta_{\mathrm{ij}} \cdot X_{\mathrm{i}} \cdot X_{\mathrm{j}}
$$


where $Y$ is the predicted response; $\beta_{0}, \beta_{\mathrm{i}}, \beta_{\mathrm{ii}}$, and $\beta_{\mathrm{ij}}$ are regression coefficients for intercept, linear, quadratic, and interaction terms, respectively, and $X_{i}$ and $X_{j}$ are the independent variables.

\subsubsection{Artificial Neural Network (ANN) Modeling}

Multi-layer perceptron (MLP) networks were developed in Statistica v.10.0 software (StatSoft Inc., Tulsa, OK, USA) for the prediction of biodiesel yield based on water content, DES composition, and mass ratio of phases. The artificial neural network (ANN) training was performed with separation of data into training, test, and validation sets in a 70:15:15 ratio. A back error propagation algorithm was applied for the model training to ensure the minimum value of the error function. The model performance was evaluated based on $R^{2}$ and root mean squared error (RMSE) values for training, testing, and validation.

\section{Results}

\subsection{Optimization of Biodiesel Synthesis and the Glycerol Extraction Process}

In order to optimize the integrated biodiesel synthesis and glycerol extraction process, the influence of three variables on biodiesel yield and extraction efficiency were analyzed at three levels.

The first chosen variable was the mass ratio of a reaction phase (oil, methanol, enzyme, and water) and a DES (ChCl:Gly or ChCl:EG) phase. According to Hayyan et al. [41], while purifying the produced biodiesel, biodiesel and the DES mass ratio have a significant impact on extraction efficiency, which is the highest for the 1:1 mass ratio. Therefore, a 1:1 mass ratio of a reaction phase (oil, methanol, enzyme, and water) and the DES phase was chosen as the initial value. To cover the entire range of phase ratios, the lower and higher levels were set to be 1:9 and 9:1, respectively.

The second analyzed variable was the mass fraction of water in the system. According to Merza et al. [42], water has a significant impact on biodiesel yield when using lipase as a catalyst, while water is necessary to keep the 3D structure of lipase. On the other hand, the water content should not be too high during the transesterification process because unwanted hydrolysis could occur [43]. Therefore, optimization of water content is necessary in order to obtain the highest possible yield.

Furthermore, based on previous research [34], the initial value was set at $4.6 \%$, while the lower level was defined considering the water content in the original enzyme sample, which resulted in the minimal water content of $0.6 \%$ in the mixture. In order to keep the optimization step of $4 \%$, the mass fraction of water was set to be $8.6 \%$ at the higher level.

The third chosen variable was the molar ratio of choline chloride and a hydrogen bond donor in a DES. Šalić et al. [33] highlighted that the extraction efficiency can be increased by changing the ratio of choline chloride and a hydrogen bond donor from 1:1 to 1:3. Therefore, the $1: 3$ molar ratio was chosen to be the initial value with step set to 1 , and 1:2 and 1:4 as the lower and higher levels of the third variable, respectively.

The experimental plan obtained by the application of the Box-Behnken design implemented in the Statistica software package and the experimentally determined response values are shown in Table 2 for both investigated DESs.

It can be noticed that biodiesel yields are generally much higher in the $\mathrm{ChCl}$ :Gly system. According to Gorke et al. [44], who reported on higher lipase activity in ChCl:Gly compared to $\mathrm{ChCl:EG}$, the reason could be the stronger hydrogen-bonding network in $\mathrm{ChCl}$ :Gly. Namely, ChCl:Gly has three hydroxyl groups (strong HBD sites), while ChCl:EG is composed of two hydroxyl groups [31]. Those HBD sites lower the chemical potential of DES components which makes DESs suitable as solvents. That way, the components, more specifically ethylene glycol or glycerol, no longer have a negative impact on the enzyme and that effect is, therefore, more pronounced with ChCl:Gly [43]. Furthermore, extraction efficiencies are also higher when using $\mathrm{ChCl}$ :Gly in most experiments. That agrees with research performed by Šalić et al. [33], where the same extraction efficiencies 
were obtained for a significantly shorter residence time in continuous experiments, where $\mathrm{ChCl}$ :Gly was used as the reaction and extraction medium. As for the glycerol content, it can be observed that purity according to standards for the direct use of biodiesel, i.e., glycerol content lower than $0.02 \%$ [18], has been achieved in only one run (run $11-0.007 \%$, Table 2). In other runs, glycerol content was significantly higher, which indicates the necessity of further optimization.

After the experiments were carried out, volume activity of lipase was measured in the phase containing DESs, because the enzyme, as well as glycerol and other possible byproducts of transesterification, is being separated by them [31]. Based on the results shown in Figure 2, there is no noticeable trend that would indicate which DES is most suitable. However, the highest volume activity was measured in run 8 with the DES ChCl:Gly (9:1 mass ratio of phases, $8.6 \%$ of water, 1:3 DES molar ratio). That can be explained by the significant impact of a certain amount of water on the activity and stability of lipase [22]. Furthermore, activity was not measured in runs 5, 6, 9, and 10 due to gel formation caused by high DES excess (10:90 mass ratio of phases). Considering all the presented results, the ChCl:Gly DES can be considered as a more suitable reaction medium compared to the ChCl:EG DES. Additionally, change in enzyme volume activity was not noticed during single experiments (30 $\mathrm{min}$ ).

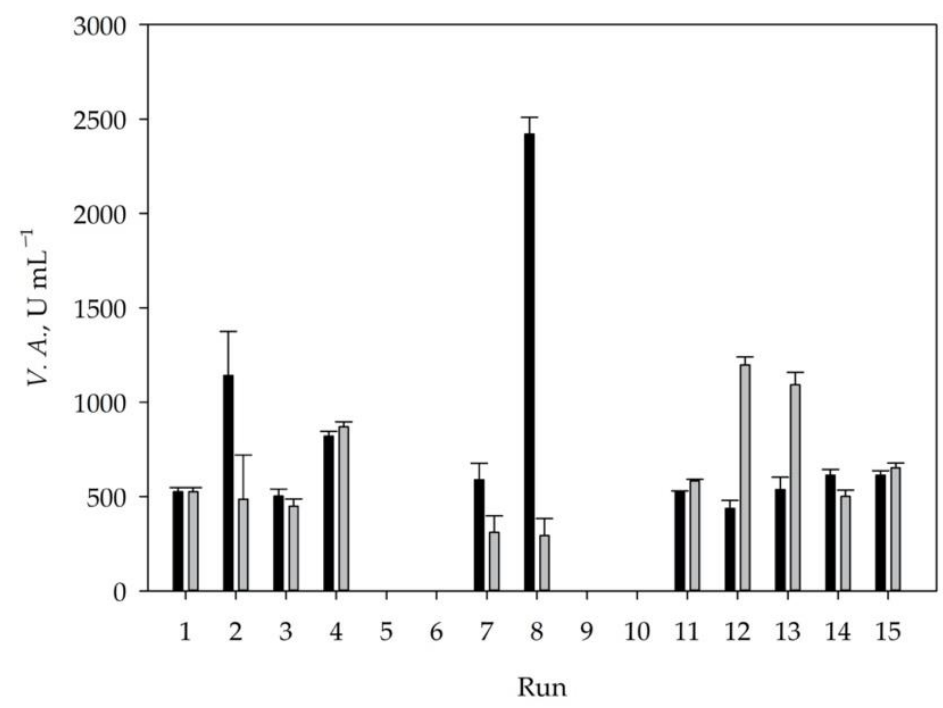

Figure 2. Volume activities of lipase for points of experimental plan according to the Box-Behnken experimental design in experiments with $\mathrm{ChCl}$ :Gly $(\bullet)$ and $\mathrm{ChCl}: \mathrm{EG}(\bullet)$.

In accordance with RSM, a second-order polynomial equation was used to describe the relationship between the response (biodiesel yield $(Y)$ ) and three variables (water content $\left(X_{1}\right)$, DES composition $\left(X_{2}\right)$, and the mass ratio of phases $\left(X_{3}\right)$ ). The estimated model parameters and ANOVA results are given in Table 3 and the RSM plot in Figure 3. According to Teng et al. [45], the variable has a significant impact on the response if $p<0.05$. The results showed that water content in the linear $(p<0.0001)$ and quadratic term $(p<0.0001)$ has a significant positive effect on biodiesel yield in the $\mathrm{ChCl}$ :Gly system. Furthermore, it can be noticed that the phase mass ratio $\left(X_{3}\right)$ has a significant negative effect in the linear term $(p=0.0055)$ and a significant positive effect in the quadratic term $(p<0.0001)$. The results also showed the significant positive effect of the $X_{1} \cdot X_{3}$ interaction term $(p=0.0009)$. Similar results were obtained for the model describing biodiesel yield in the ChCl:EG system, where the water content in the linear term $(p<0.0001)$, the phase ratio in the linear term $(p<0.0001)$, and the $X_{1} \cdot X_{3}$ interaction term $(p<0.0001)$ showed a significant positive effect on biodiesel yield. 
Table 3. Analysis of variance of response surface methodology (RSM) models for biodiesel yield. (Sum of squares (SS), Degree of freedom (DF), Mean square (MS)).

\begin{tabular}{|c|c|c|c|c|c|c|c|}
\hline \multirow[b]{2}{*}{ Source } & \multicolumn{7}{|c|}{ ChCl:Gly } \\
\hline & Coeff. \pm st.er. & SS & DF & MS & F-Value & $p$-Value & $R^{2}$ \\
\hline Model & & 3347.14 & 9 & 371.90 & 31.43 & $<0.0001$ & 0.9452 \\
\hline Intercept & $17.98 \pm 1.34$ & & & & & & \\
\hline$X_{1}$ & $49.80 \pm 3.30$ & 3133.08 & 1 & 3133.08 & 227.13 & $<0.0001$ & \\
\hline$X_{2}$ & $2.67 \pm 1.86$ & 28.53 & 1 & 28.53 & 2.07 & 0.1658 & \\
\hline$X_{3}$ & $-5.78 \pm 1.86$ & 133.50 & 1 & 133.50 & 9.68 & 0.0055 & \\
\hline$X_{1}^{2}$ & $24.07 \pm 2.73$ & 1069.34 & 1 & 1069.34 & 77.52 & $<0.0001$ & \\
\hline$X_{2}^{2}$ & $5.01 \pm 1.37$ & 185.62 & 1 & 185.62 & 13.45 & 0.0015 & \\
\hline$X_{3}^{2}$ & $9.49 \pm 1.37$ & 665.74 & 1 & 665.74 & 48.26 & $<0.0001$ & \\
\hline$X_{1} \cdot X_{2}$ & $-1.81 \pm 2.63$ & 6.58 & 1 & 6.58 & 0.48 & 0.4974 & \\
\hline$X_{1} \cdot X_{3}$ & $10.17 \pm 2.63$ & 206.73 & 1 & 206.73 & 14.98 & 0.0009 & \\
\hline$X_{2} \cdot X_{3}$ & $3.82 \pm 2.63$ & 29.26 & 1 & 29.26 & 2.12 & 0.1608 & \\
\hline Residual & & 224.81 & 20 & 11.83 & & & \\
\hline Lack of fit & & 148.80 & 3 & 14.40 & 1.664 & 0.0667 & \\
\hline \multirow[t]{2}{*}{ Pure error } & & 76.02 & 17 & 4.47 & & & \\
\hline & \multicolumn{7}{|c|}{ ChCl:EG } \\
\hline Source & Coeff. \pm st.er. & SS & DF & MS & F-Value & $p$-Value & $R^{2}$ \\
\hline Model & & 1601.69 & 9 & 177.97 & 46.21 & $<0.0001$ & 0.9541 \\
\hline Intercept & $8.39 \pm 0.71$ & & & & & & \\
\hline$X_{1}$ & $12.39 \pm 1.75$ & 193.22 & 1 & 193.22 & 50.17 & $<0.0001$ & \\
\hline$X_{2}$ & $1.25 \pm 0.98$ & 6.24 & 1 & 6.24 & 1.62 & 0.2176 & \\
\hline$X_{3}$ & $11.14 \pm 0.98$ & 496.32 & 1 & 496.32 & 128.86 & $<0.0001$ & \\
\hline$X_{1}^{2}$ & $-1.39 \pm 1.44$ & 3.57 & 1 & 3.57 & 0.93 & 0.3473 & \\
\hline$X_{2}^{2}$ & $0.75 \pm 0.72$ & 4.10 & 1 & 4.10 & 1.07 & 0.3143 & \\
\hline$X_{3}^{2}$ & $-1.54 \pm 0.72$ & 17.43 & 1 & 17.43 & 4.52 & 0.0460 & \\
\hline$X_{1} \cdot X_{2}$ & $0.43 \pm 1.38$ & 0.378 & 1 & 0.378 & 0.09 & 0.7574 & \\
\hline$X_{1} \cdot X_{3}$ & $12.39 \pm 1.38$ & 307.42 & 1 & 307.42 & 79.82 & $<0.0001$ & \\
\hline$X_{2} \cdot X_{3}$ & $2.02 \pm 1.38$ & 8.16 & 1 & 8.16 & 2.12 & 0.1610 & \\
\hline Residual & & 177.03 & 20 & 3.85 & & & \\
\hline Lack of fit & & 155.47 & 3 & 8.49 & 1.458 & 0.0937 & \\
\hline Pure error & & 21.55 & 17 & 1.27 & & & \\
\hline
\end{tabular}

To highlight the interactive effects of the independent variables on biodiesel yield, 3D response surfaces are presented in Figure 3. The plots were obtained by presenting the response variable versus two independent variables (the third was kept constant). For the ChCl:Gly system (Figure 3(a1-c1)), it can be noticed that biodiesel yield increases with the water content increase until the optimum water counter value is reached. Furthermore, biodiesel yield decreases with the increase in the mass ratio of phases. In case of the $\mathrm{ChCl}$ :EG system (Figure 3(a2-c2)), biodiesel yield increased with the water content increase, the DES composition increase, and the increase in the mass ratio of phases.

Based on the $R^{2}$ values of the developed RSM models ( 0.9452 for the ChCl:Gly system and 0.9541 for the $\mathrm{ChCl}$ :EG system), it can be concluded that the RSM models describe the experimental data with high precision. As previously presented by Le Man et al. [46], the model is considered adequate when $R^{2}>0.75$, which was achieved. Analysis of variance (ANOVA) showed that the proposed models were significant $(p<0.05)$ and that the F-values for the models were higher than the F-critical $=2.007(\mathrm{~F}(\mathrm{ChCl}: \mathrm{Gly})=31.43$, $\mathrm{F}(\mathrm{ChCl}: \mathrm{EG})=46.21)$.

Taking into account that the high $R^{2}$ value does not guarantee that the model will fit the data well, residual analysis was also performed. Results of the residual analysis are presented in Figure 4. Residuals were arranged nearly around the line (Figure 4(a1,a2)) and the histograms presenting the classification of residuals (Figure $4(\mathrm{c} 1, \mathrm{c} 2)$ ) showed a specific bell shape, and therefore, the assumption on normality was convinced. Moreover, 
by analyzing the plots showing residuals versus predicted values (Figure 4(b1,b2)), it can be noticed that residuals were randomly distributed, demonstrating good agreement between model and experimental data. Residual analysis also showed that the order of the experimental run cannot change the results because residuals alter close to zero (Figure $4(\mathrm{~d} 1, \mathrm{~d} 2))$. The obtained results indicated the reliability of the developed response surface model for the analyzed range of input variables.

(a1)

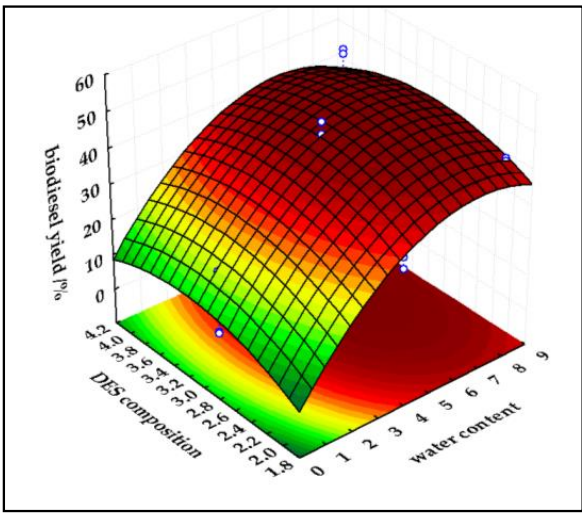

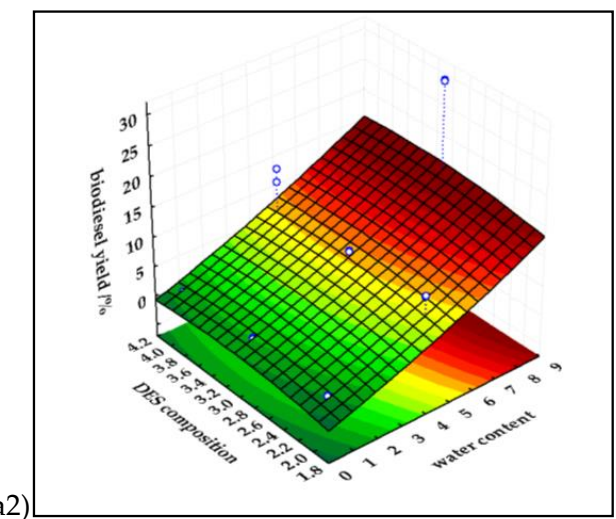

(a)

(b1)
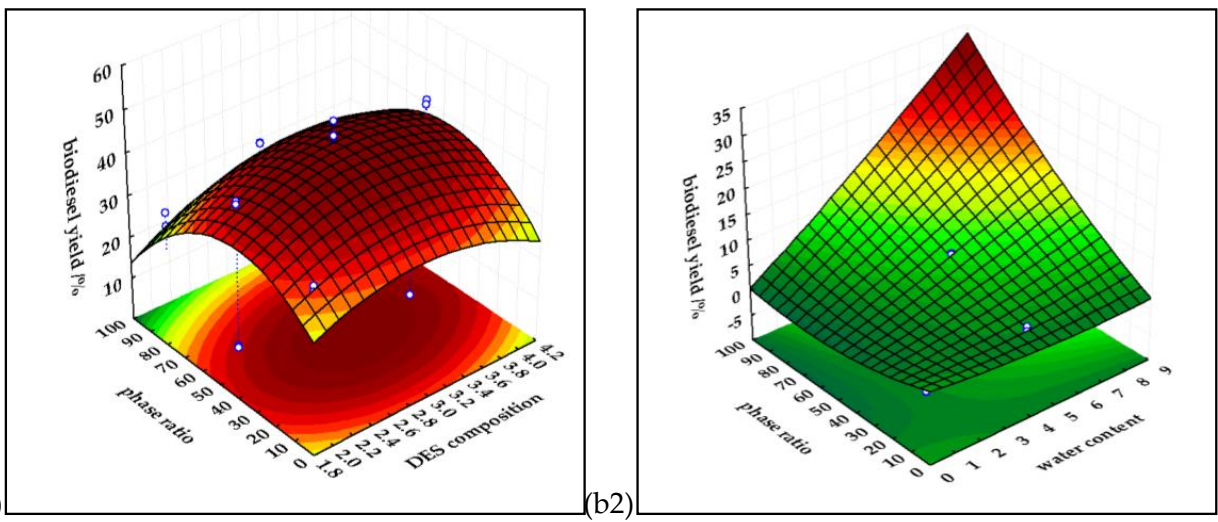

(b)
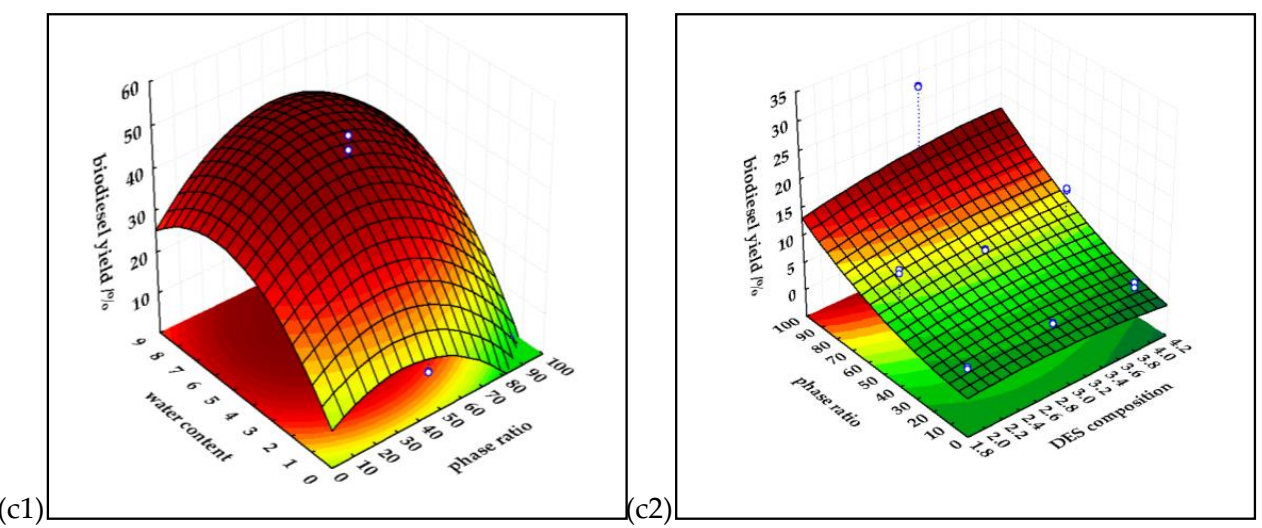

(c)

Figure 3. Response surface plot for biodiesel production and purification obtained by numerical optimization as a function of statistically significant interaction variables: (a) DES composition, (b) water content, and (c) ratio of phases. 

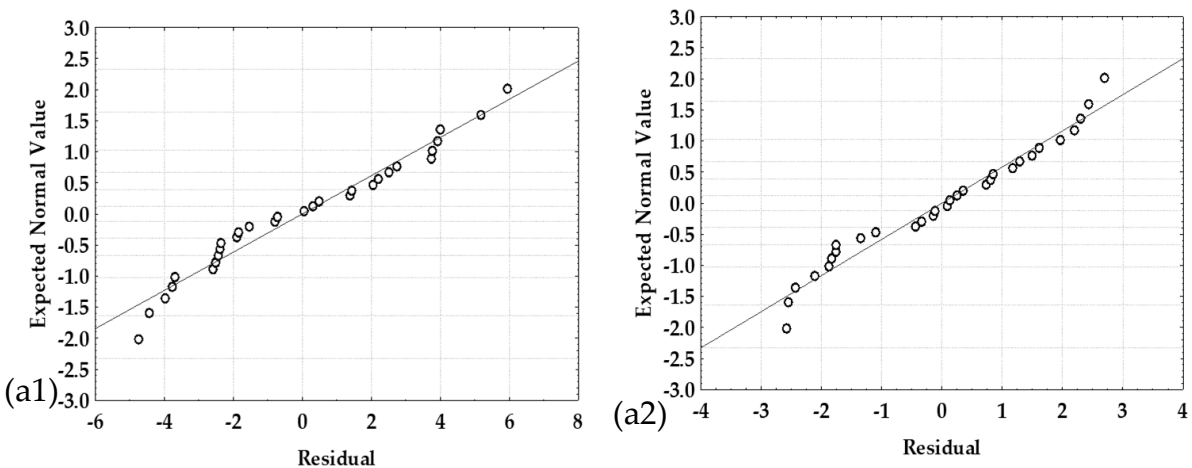

(a)
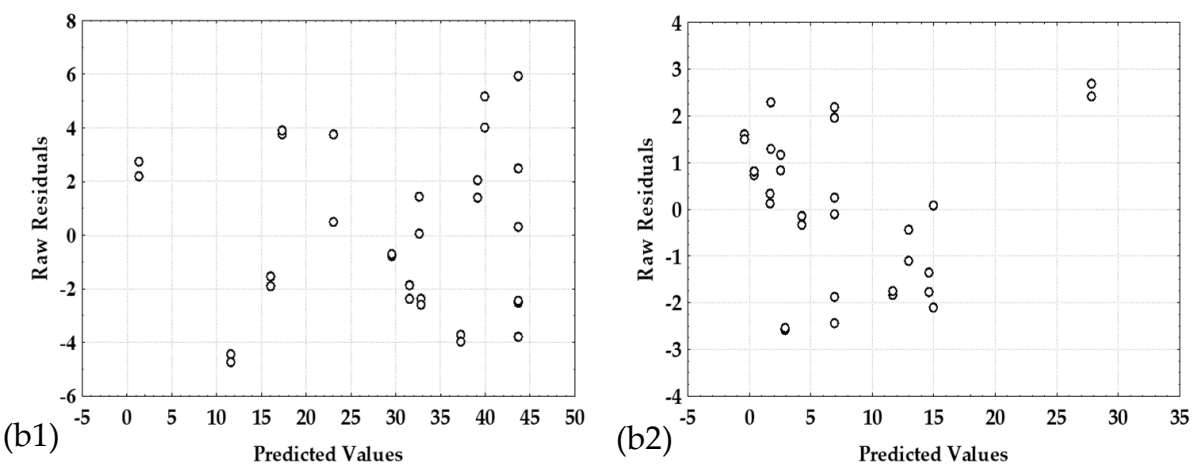

(b)
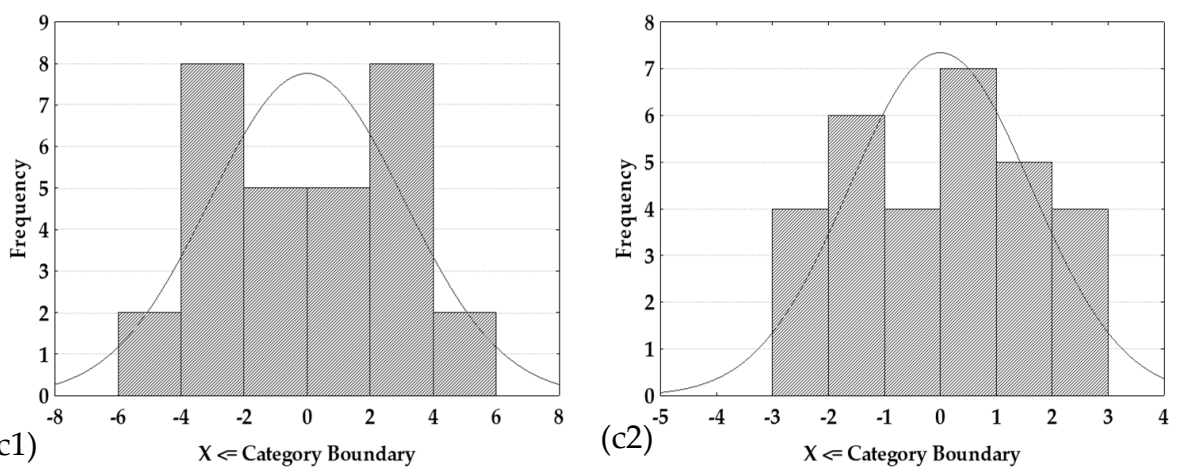

(c)
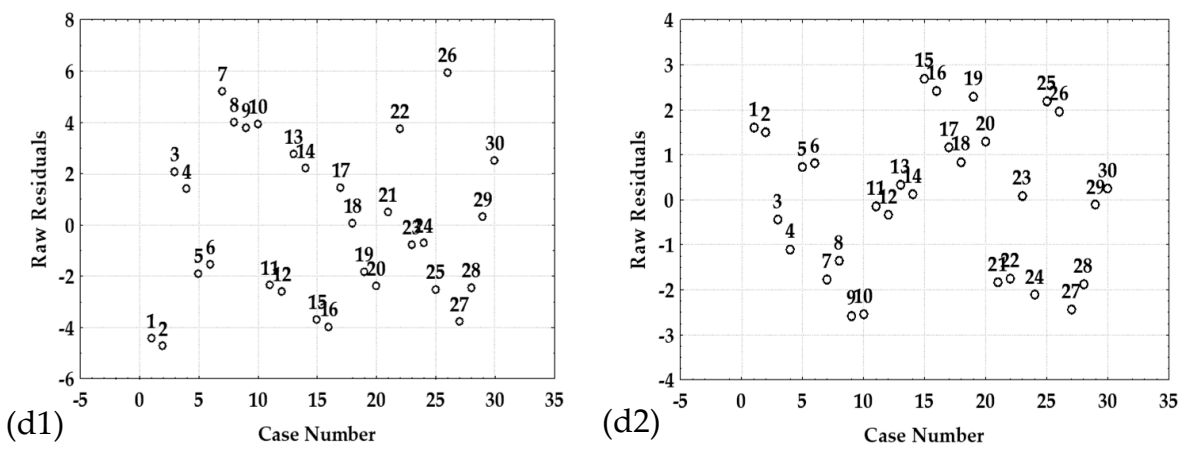

(d)

Figure 4. Residual analysis for the response surface regression of the biodiesel yield: (1) ChCl:-Gly, (2) ChCl:-EG. (a) Normal probability plot of the residuals; (b) residuals versus the predicted values; (c) histogram of the residuals; (d) residuals versus the order of the data. 
Furthermore, optimization was performed based on the desirability profiles obtained from the RSM predicted values. The desirability scale in the range from 0 (undesirable) to 1 (very desirable) was used. Since the optimization of two processes was carried out, there were cases in which it was not possible to achieve the maximum response of both processes under the same conditions (process variables). In those cases, the optimal conditions were those that correspond to the maximum biodiesel yield since the values of glycerol extraction efficiency are generally high and their changes with the changes in process variables are not as pronounced as in the case of biodiesel yield. Therefore, the optimal conditions for integrated biodiesel synthesis and glycerol extraction regarding biodiesel yield were the following: water mass content $6.6 \%$, molar ratio of DES constituents 1:3.5, and mass ratio of phases 1:1. The performance of the developed RSM model for the prediction of glycerol extraction regrading biodiesel yield was evaluated under selected optimal process conditions. As presented in Table 4 for experiment III, glycerol extraction regarding biodiesel yield of $43.54 \pm 0.2 \%$ was obtained, which was not significantly different $(p>0.05)$ from the model-predicted value of $47.13 \%$. It can be concluded that the RSM model can efficiently predict the glycerol extraction regarding biodiesel yield.

Table 4. Comparison of biodiesel yield, extraction efficiency, and glycerol content under different initial conditions of biodiesel synthesis and purification.

\begin{tabular}{ccccc}
\hline & \multicolumn{2}{c}{ Buffer } & \multicolumn{2}{c}{ ChCl:Gly } \\
\cline { 2 - 5 } & \multicolumn{2}{c}{ Initial Conditions } & \multicolumn{2}{c}{ Optimal Conditions } \\
\cline { 2 - 5 } & Experiment I & Experiment II & Experiment III & Experiment IV \\
\hline \multicolumn{4}{c}{ Batch reactor } & Microsystem \\
\hline$Y, \%$ & $61.61 \pm 1.99$ & $43.01 \pm 1.23$ & $43.54 \pm 0.2$ & $45.33 \pm 1.74$ \\
$\eta, \%$ & - & $97.52 \pm 0.9$ & $99.54 \pm 0.19$ & $99.56 \pm 0.13$ \\
$w_{\mathrm{G}}, \%$ & $7.84 \pm 0.51$ & $0.15 \pm 0.11$ & $0.027 \pm 0.01$ & $0.019 \pm 0.003$ \\
\hline
\end{tabular}

\subsection{Artificial Neural Networks (ANN) Modelling}

In order to additionally enhance the description and prediction of biodiesel yield, MLP models were proposed. The networks selected based on their performance are given in Table 5. For the system with the ChCl:Gly, MLP 3-9-1 was selected as the optimum. The described ANN ensured good agreement between the experimental data and the model-predicted data for training, testing, and validation $\left(R^{2}>0.9900\right)$. The selected MLP was characterized by three neurons in the input layer, nine neurons in the hidden layer, and one neuron in the output layer, and the hidden activation function was exponential, while the output activation function was the identity function. The ANN selected as the optimum for the prediction of biodiesel yield in the system with the ChCl:EG was MLP 3-8-1 and it showed very good agreement between the model and the experiment for training, testing, and validation $\left(R^{2}>0.9690\right)$. In order to determine the influence of input variables on the output, a global sensitivity analysis was performed. A higher global sensitivity coefficient corresponds to a higher influence of the input. It can be noticed that water content has the most significant effect on the biodiesel yield for both systems (global sensitivity coefficient around $60 \%$ ), followed by the phase ratio with sensitivity around 30\% (Figure 5). As for the RSM model, the DES composition showed to be the least important variable. 
Table 5. Architectures of artificial neural networks (ANNs) selected for prediction of biodiesel yield. Selected architectures are marked bold.

\begin{tabular}{|c|c|c|c|c|c|c|}
\hline & $\begin{array}{c}\text { Network } \\
\text { Name }\end{array}$ & $\begin{array}{l}\text { Training } \\
\text { Perf./Training } \\
\text { Error }\end{array}$ & $\begin{array}{c}\text { Test } \\
\text { Perf./Test } \\
\text { Error }\end{array}$ & $\begin{array}{c}\text { Validation } \\
\text { Perf./Validation } \\
\text { Error }\end{array}$ & $\begin{array}{l}\text { Hidden } \\
\text { Activation } \\
\text { Function }\end{array}$ & $\begin{array}{l}\text { Output } \\
\text { Activation } \\
\text { Function }\end{array}$ \\
\hline \multirow{10}{*}{ 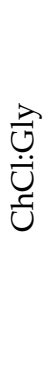 } & \multirow{2}{*}{ MLP 3-9-1 } & 0.9977 & 0.9968 & 0.9906 & \multirow{2}{*}{ Exponential } & \multirow{2}{*}{ Identity } \\
\hline & & 0.0003 & 0.0006 & 0.0007 & & \\
\hline & \multirow{2}{*}{ MLP 3-8-1 } & 0.9977 & 0.9855 & 0.9339 & \multirow{2}{*}{ Exponential } & \multirow{2}{*}{ Logistic } \\
\hline & & 0.0006 & 0.0011 & 0.0013 & & \\
\hline & \multirow{2}{*}{ MLP 3-5-1 } & 0.9977 & 0.9753 & 0.9635 & \multirow{2}{*}{ Exponential } & \multirow{2}{*}{ Logistic } \\
\hline & & 0.0004 & 0.0016 & 0.0019 & & \\
\hline & \multirow{2}{*}{ MLP 3-8-1 } & 0.9977 & 0.9844 & 0.9812 & \multirow{2}{*}{ Exponential } & \multirow{2}{*}{ Logistic } \\
\hline & & 0.0003 & 0.0006 & 0.0012 & & \\
\hline & \multirow{2}{*}{ MLP 3-9-1 } & 0.9977 & 0.9852 & 0.9828 & \multirow{2}{*}{ Logistic } & \multirow{2}{*}{ Logistic } \\
\hline & & 0.0004 & 0.0016 & 0.0019 & & \\
\hline \multirow{10}{*}{ 崩 } & \multirow{2}{*}{ MLP 3-8-1 } & 0.9911 & 0.9684 & 0.9489 & \multirow{2}{*}{ Exponential } & \multirow{2}{*}{ Exponential } \\
\hline & & 0.0007 & 0.0008 & 0.0017 & & \\
\hline & \multirow{2}{*}{ MLP 3-6-1 } & 0.9913 & 0.9741 & 0.9689 & \multirow{2}{*}{ Exponential } & \multirow{2}{*}{ Exponential } \\
\hline & & 0.0007 & 0.0007 & 0.0015 & & \\
\hline & \multirow{2}{*}{ MLP 3-7-1 } & 0.9911 & 0.9698 & 0.9680 & \multirow{2}{*}{ Exponential } & \multirow{2}{*}{ Exponential } \\
\hline & & 0.0007 & 0.0008 & 0.0017 & & \\
\hline & \multirow{2}{*}{ MLP 3-4-1 } & 0.9852 & 0.9688 & 0.9664 & \multirow{2}{*}{ Exponential } & \multirow{2}{*}{ Logistic } \\
\hline & & 0.0007 & 0.0014 & 0.0014 & & \\
\hline & \multirow{2}{*}{ MLP 3-8-1 } & 0.9906 & 0.9798 & 0.9692 & \multirow{2}{*}{ Exponential } & \multirow{2}{*}{ Exponential } \\
\hline & & 0.0006 & 0.0007 & 0.0008 & & \\
\hline
\end{tabular}

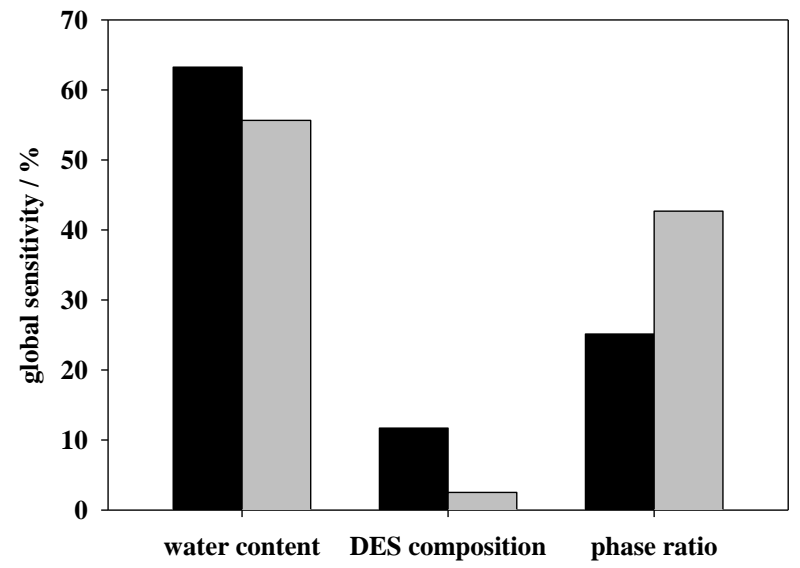

Figure 5. Global sensitivity analysis of optimal ANN architectures: (•) ChCl:Gly, (•) ChCl:EG.

\subsection{Integrated Production and Purification of Biodiesel-Batch Reactor versus Microreactor}

After the process optimization, three additional experiments on a laboratory shaker $\left(t=2 \mathrm{~h}, 400 \mathrm{rpm}\right.$, and $T=40{ }^{\circ} \mathrm{C}$ ) were performed. In Experiment $\mathrm{I}$, the initial conditions were the same as in previous research $[20,28]$. After $2 \mathrm{~h}$, the obtained yield was $61.61 \%$, as presented in Table 4 . In order to obtain biodiesel $(Y>96 \%)$, the process needs to be performed for $24 \mathrm{~h}$ [47]. As mentioned before, in order to enhance the process and to perform parallel biodiesel synthesis and purification, a DES was introduced in the system instead of a buffer. Two experiments were performed using a DES as the reaction and extraction medium. Experiment II was performed under initial conditions, while Experiments III and IV were performed under the optimal conditions.

As can be seen from results shown in Table 4, in both reaction systems, batch and microreactor, for experiments performed with a DES (Experiments II, III, and IV), a slightly lower yield in comparison to Experiment I was obtained. The reason for this is probably a decrease in enzyme activity for reactions performed with a DES. According to Xu et al. [48], 
the constituting components of a DES can have an inhibitory effect on enzyme activity by changing the secondary structure of the enzyme.

On the other hand, although the biodiesel yield was lower, in all experiments performed with a DES, the mass fraction of glycerol in biodiesel was lower in comparison to Experiment I. Comparing the results of Experiments II and III, it is clear that the optimization goal was achieved, since both the yield and the extraction efficiency were higher in Experiment III conducted under optimal conditions. Furthermore, the mass fraction of glycerol achieved in Experiment III has a value close to that prescribed by the international standard EN 14214:2012+A2:2019 [6].

According to literature [29], extraction efficiency could be enhanced by using a higher temperature. Higher temperatures should reduce glycerol retention, as it was observed in the studies where the effect of temperature on glycerol removal was brought into relation with the concentration factor (CF). According to Saleh at al. [49], higher temperatures promote reaching the appropriate $\mathrm{CF}$ value sooner, so glycerol separates from the FAMErich phase faster. Additionally, increasing the temperature can be another advantage for biodiesel purification, because higher temperatures facilitate the circulation of biodiesel by considerably decreasing its viscosity, reducing the cost of pumping in the meantime [50]. To examine the impact of temperature increase on extraction efficiency, the integrated process of biodiesel production and purification in a batch reactor was carried out at three different temperatures $\left(40^{\circ} \mathrm{C}, 50^{\circ} \mathrm{C}\right.$, and $\left.60^{\circ} \mathrm{C}\right)$ under optimal conditions determined in experiments performed with ChCl:Gly. The highest yield of biodiesel was achieved at the temperature of $40{ }^{\circ} \mathrm{C}$ (temperature optimum for lipase activity). By increasing the temperature, the biodiesel yield decreases significantly. At a temperature of $50{ }^{\circ} \mathrm{C}$, the yield was 1.42 times lower, while at $60^{\circ} \mathrm{C}$, it was 3.07 times lower in comparison to the value obtained at $40^{\circ} \mathrm{C}$. On the other hand, the extraction efficiency did not change significantly, indicating that enhancing the temperature does not have a positive effect on the integrated process.

As one of the solutions for the further intensification of the process, a change in the reactor type was proposed and the batch reactor was replaced by the tubular PTFE microreactor. It was expected that due to the specific design of the microreactor and the associated advantages in terms of the mass and energy transfer, an increased biodiesel yield and glycerol extraction efficiency could be expected. Therefore, integrated biodiesel production and purification was performed in a microsystem (Experiment IV). As it can be seen from results shown in Table 4, an increase in both yield and extraction efficiency was obtained in the microsystem. At the same time, free glycerol content was below the level prescribed by standards. The results indicated that the microsystem should be a focus for further process optimization.

\section{Conclusions}

An integrated biodiesel production process, composed of biodiesel synthesis from edible sunflower oil and methanol, catalyzed by the enzyme lipase from Thermomyces lanuginosus, with simultaneous extraction of glycerol using deep eutectic solvents as the reaction and extraction media was performed. The highest biodiesel yield and extraction efficiency were obtained in experiments performed with the ChCl:Gly DES, which was selected as a more suitable reaction and extraction medium for carrying out this integrated process in comparison to the $\mathrm{ChCl}$ :EG DES.

Optimal conditions for biodiesel synthesis and parallel glycerol extraction processes determined by numerical optimization and confirmed by an independent experiment were achieved at the mass ratio of phases of 1:1, the mass fraction of water of $6.6 \%$, and a molar ratio of ChCl:Gly 1:3.5. The effect of temperature on the efficiency of glycerol extraction was found to be negligible. When the reaction was performed in a microsystem, additional process intensification was achieved, leading to the product that had free glycerol content below the international standards, which is a good base for further development of the single-stage biodiesel-integrated production/purification process on the microscale. 
Additionally, the obtained results can be used for future research and sustainable development where waste oils, in combination with enzyme produced from waste feedstocks, could be applied for biodiesel production.

Author Contributions: Conceptualization, A.Š.; methodology, M.B., A.L., M.G. and A.Š.; software, A.J.T.; formal analysis, M.G. and A.J.T.; investigation, M.B., A.L. and M.G.; data curation, M.G. and A.J.T.; writing—original draft preparation, M.B., A.L., M.G. and A.J.T.; writing—review and editing, A.Š. and B.Z.; visualization, A.Š.; supervision, B.Z.; project administration, B.Z.; funding acquisition, B.Z. All authors have read and agreed to the published version of the manuscript.

Funding: This work was fully supported by the Croatian Science Foundation under the project IP-2016-06-7993.

Institutional Review Board Statement: Not applicable.

Informed Consent Statement: Not applicable.

Data Availability Statement: Not applicable.

Conflicts of Interest: The authors declare no conflict of interest.

\section{List of Symbols and Abbreviations}

\begin{tabular}{|c|c|}
\hline$t$ & Time (h) \\
\hline$T$ & Temperature $\left({ }^{\circ} \mathrm{C}\right)$ \\
\hline Y & Yield $(\%)$ \\
\hline$V$ & Reactor volume (mL) \\
\hline$X$ & Independent variables (-) \\
\hline$w$ & Mass fraction (\%) \\
\hline \multicolumn{2}{|c|}{ Greek letters } \\
\hline$\beta$ & Regression coefficients (-) \\
\hline$\gamma$ & Mass concentration $\left(\mathrm{mg} \mathrm{mL}^{-1}\right)$ \\
\hline$\lambda$ & Wavelength (nm) \\
\hline$\eta$ & Extraction efficiency (\%) \\
\hline$\tau$ & Residence time (s) \\
\hline \multicolumn{2}{|c|}{ Abbreviations } \\
\hline ANN & Artificial neural networks \\
\hline ChCl:Gly & Choline chloride:glycerol \\
\hline ChCl:EG & Choline chloride:ethylene glyco \\
\hline DES & Deep eutectic solvent(s) \\
\hline DF & Degree of freedom \\
\hline E & Enzyme \\
\hline FAME & Fatty acid methyl ester(s) \\
\hline FID & Flame ionization detector \\
\hline HBD & Hydrogen bond donor \\
\hline HBA & Hydrogen bond acceptor \\
\hline MLP & Multi-layer perceptron \\
\hline MS & Mean square \\
\hline PTFE & Polytetrafluoroethylene \\
\hline RMSE & Root mean squared error \\
\hline RSM & Response surface methodology \\
\hline SS & Sum of squares \\
\hline
\end{tabular}

\section{References}

1. Franjo, M.; Šalić, A.; Zelić, B. Microstructured devices for biodiesel production by transesterification. Biomass Conv. Bioref. 2018, 8, 1005-1020. [CrossRef]

2. Chattopadhyay, S.; Sen, R. Fuel properties, engine performance and environmental benefits of biodiesel produced by a green process. Appl. Energy 2013, 105, 319-326. [CrossRef]

3. Chang, W.R.; Hwang, J.J.; Wu, W. Environmental impact and sustainability study on biofuels for transportation applications. Renew. Sustain. Energy Rev. 2017, 67, 277-288. [CrossRef] 
4. De Oliveira, F.C.; Coelho, S.T. History, evolution, and environmental impact of biodiesel in Brazil: A review. Renew. Sustain. Energy Rev. 2017, 75, 168-179. [CrossRef]

5. Mandal, B.; Palit, S.; Chowdhuri, A.K.; Mandal, B.K. Environmental impact of using biodiesel as fuel in transportation: A review. Int. J. Glob. Warm. 2011, 3, 232. [CrossRef]

6. Gojun, M.; Bačić, M.; Ljubić, A.; Šalić, A.; Zelić, B. Transesterification in microreactors-Overstepping obstacles and shifting towards biodiesel production on a microscale. Micromachines 2020, 11, 457. [CrossRef] [PubMed]

7. Sharma, K.S. Improvement of biodiesel product yield during simple consecutive-Competitive reactions. J. Encapsulation Adsorpt. Sci. 2015, 5, 204-216. [CrossRef]

8. Šalić, A.; Jurinjak Tušek, A.; Sander, A.; Zelić, B. Lipase catalysed biodisel synthesis with integrated glycerol separation in continuously operated michrochips connected in series. New Biotechnol. 2018, 47, 80-88. [CrossRef] [PubMed]

9. Alajmi, F.S.M.D.A.; Hairuddin, A.A.; Adam, N.M.; Abdullah, L.C. Recent trends in biodiesel production from commonly used animal fats. Int. J. Energy Res. 2018, 42, 885-902. [CrossRef]

10. Kim, K.H.; Lee, O.K.; Lee, E.Y. Nano-immobilized biocatalysts for biodiesel production from renewable and sustainable resources. Catalysts 2018, 8, 68 .

11. Roman-Figueroa, C.; Olivares-Carrillo, P.; Paneque, M.; Palacios-Nereo, F.J.; Quesada-Medina, J. High-yield production of biodiesel by non-catalytic supercritical methanol transesterification of crude castor oil (Ricinus communis). Energy 2016, 107, 165-171. [CrossRef]

12. Aboelazayem, O.; Gadalla, M.; Saha, B. Biodiesel production from waste cooking oil via supercritical methanol: Optimisation and reactor simulation. Renew. Energy 2018, 124, 144-154. [CrossRef]

13. Farobie, O.; Matsumura, Y. State of the art of biodiesel production under supercritical conditions. Prog. Energy Combust. Sci. 2017, 63, 173-203. [CrossRef]

14. Gebremariam, S.N.; Marchetti, J.M. Biodiesel production technologies: Review. AIMS Energy 2017, 5, 425-457. [CrossRef]

15. Bora, P.; Boro, J.; Konwar, L.J.; Deka, D. Formulation of microemulsion based hybrid biofuel from waste cooking oil-A comparative study with biodiesel. J. Energy Inst. 2016, 89, 560-568. [CrossRef]

16. Attaphong, C.; Do, L.; Sabatini, D.A. Vegetable oil-based microemulsions using carboxylate-based extended surfactants and their potential as an alternative renewable biofuel. Fuel 2012, 94, 606-613. [CrossRef]

17. Salmani, M.H.; Rehman, S.; Zaidi, K.; Hasan, A.K. Study of ignition characteristics of microemulsion of coconut oil under off diesel engine conditions. Eng. Sci. Technol. Int. J. 2015, 18, 318-324. [CrossRef]

18. Liquid Petroleum Products-Fatty Acid Methyl Esters (FAME) for Use in Diesel Engines and Heating ApplicationsRequirements and Test Methods (EN 14214:2012+A2:2019). Available online: https://www.en-standard.eu/bs-en-14214-20 12-a2-2019-liquid-petroleum-products.-fatty-acid-methyl-esters-fame-for-use-in-diesel-engines-and-heating-applications. -requirements-and-test-methods / (accessed on 1 January 2021).

19. Zhang, L.; Xie, T.; Xu, N. Biodiesel synthesis in microreactors. Green Process. Synth. 2012, 1, 61-70.

20. Šalić, A.; Zelić, B. Synergy of microtechnology and biotechnology: Microreactors as an effective tool for processes. Food Technol. Biotechnol. 2018, 56, 464-479. [CrossRef]

21. Lam, M.K.; Lee, K.T.; Mohamed, A.R. Homogeneous, heterogeneous and enzymatic catalysis for transesterification of high free fatty acid oil (waste cooking oil) to biodiesel: A review. Biotechnol. Adv. 2010, 28, 500-518. [CrossRef]

22. Fernandez-Lafuente, R. Lipase from Thermomyces lanuginosus: Uses and prospects as an industrial biocatalyst. J. Mol. Catal. B Enzym. 2010, 62, 197-212. [CrossRef]

23. Madhawan, A.; Arora, A.; Das, J.; Kuila, A.; Sharma, V. Microreactor technology for biodiesel production: A review. Biomass Convers. Biorefin. 2018, 8, 485-496. [CrossRef]

24. Aghel, B.; Mohadesi, M.; Sahraei, S. Effect of different cosolvents on transesterification of waste cooking oil in a microreactor. Chem. Eng. Technol. 2018, 41, 598-605. [CrossRef]

25. Quitain, A.T.; Mission, E.G.; Sumigawa, Y.; Sasaki, M. Supercritical carbon dioxide-mediated esterification in a microfluidic reactor. Chem. Eng. Process 2018, 123, 168-173. [CrossRef]

26. Aghel, B.; Mohadesi, M.; Sahraei, S.; Shariatifar, M. New heterogeneous process for continuous biodiesel production in microreactors. Can. J. Chem. Eng. 2017, 95, 1280-1287. [CrossRef]

27. Santana, H.S.; Silva, J.L.; Tortola, D.S.; Taranto, O.P. Transesterification of sunflower oil in microchannels with circular obstructions. Chin. J. Chem. Eng. 2018, 26, 852-863. [CrossRef]

28. Ho, K.C.; Shahbaz, K.; Rashmi, W.; Mjalli, F.S.; Hashim, M.A.; Alnashef, I.M. Removal of glycerol from palm oil-based biodiesel using new ionic liquids analogues. J. Eng. Sci. Technol. 2015, 10, 98.

29. Petračić, A.; Sander, A.; Magić, L. Separation of free glycerol and glycerides from biodiesel by means of liquid-liquid extraction. Sci. J. Energy Eng. 2017, 5, 87-94. [CrossRef]

30. Homan, T.; Shahbaz, K.; Farid, M.M. Improving the production of propyl and butyl esters-based biodiesel by purification using deep eutectic solvents. Sep. Purif. Technol. 2017, 174,570-576. [CrossRef]

31. Cvjetko Bubalo, M.; Jurinjak Tušek, A.; Vinković, M.; Radošević, K.; Gaurina Srček, V.; Radojčić Redovniković, I. Cholinium-based deep eutectic solvents and ionic liquids for lipase-catalyzed synthesis of butyl acetate. J. Mol. Catal. B Enzym. 2015, 122, 188-198. [CrossRef] 
32. Tang, S.; Baker, G.A.; Zhao, H. Ether- and alcohol-functionalized task-specific ionic liquids: Attractive properties and applications. Chem. Soc. Rev. 2012, 41, 4030-4066. [CrossRef] [PubMed]

33. Šalić, A.; Jurinjak Tušek, A.; Gojun, M.; Zelić, B. Biodiesel purification in microextractors: Choline chloride based deep eutectic solvents vs water. Sep. Purif. Technol. 2020, 242, 116783. [CrossRef]

34. Gotor-Fernandez, V.; Paul, C.E. Deep eutectic solvents for redox biocatalysis. J. Biotechnol. 2019, 293, 24-35. [CrossRef] [PubMed]

35. Miličević, N.; Panić, M.; Valinger, D.; Cvjetko Bubalo, M.; Benković, M.; Jurina, T.; Gajdoš Kljusurić, J.; Radojčić Redovniković, I.; Jurinjak Tušek, A. Developement of continuously operated aqueous two-phase microextraction process using natural deep eutectic solvents. Sep. Purif. Technol. 2020, 244, 116746. [CrossRef]

36. Bas, D.; Boyac, I.H. Modeling and optimization I: Usability of response surface methodology. J. Food Eng. 2007, 78, 836-845. [CrossRef]

37. Bezzera, M.A.; Santelli, R.E.; Oliveira, E.P.; Villar, L.S.; Escaleira, L.A. Response surface methodology (RSM) as a tool for optimization in analytical chemistry. Talanta 2008, 76, 965-977. [CrossRef]

38. Budžaki, S.; Šalić, A.; Zelić, B.; Tišma, M. Enzyme-catalysed biodiesel production from edible and waste cooking oils. Chem. Biochem. Eng. Q. 2015, 29, 329-333.

39. Bondioli, P.; Della Bella, L. An alternative spectrophotometric method for the determination of free glycerol in biodiesel. Eur. J. Lipid Sci. Technol. 2005, 107, 153-157. [CrossRef]

40. Chumuang, N.; Punsuvon, V. Response surface methodology for biodiesel production using calcium methoxide catalyst assisted with tetrahydrofuran as cosolvent. J. Chem. 2017, 2017, 4190818. [CrossRef]

41. Hayyan, M.; Mjalli, F.S.; Hashim, M.A.; AlNashef, I.M. A novel technique for separating glycerine from palm oil-based biodiesel using ionic liquids. Fuel Process. Technol. 2010, 91, 116-120. [CrossRef]

42. Merza, F.; Fawzy, A.; Al Nashef, I.; Al-Zuhair, S.; Taher, H. Effectiveness of using deep eutectic solvents in enzymatic biodiesel production from waste oils. Energy Rep. 2018, 4, 77-83. [CrossRef]

43. Lu, J.; Chen, Y.; Wang, F.; Tan, T. Effect of water on methanolysis of glycerol trioleate catalyzed by immobilized lipase Candida sp. 99-125 in organic solvent system. J. Mol. Catal. B Enzym. 2009, 56, 122-125. [CrossRef]

44. Gorke, J.T.; Srienc, F.; Kazlauskas, R.J. Hydrolase-catalyzed biotransformations in deep eutectic solvents. Chem. Commun. 2008, 10, 1235-1237. [CrossRef] [PubMed]

45. Teng, D.; Fang, Y.; Song, X.; Gao, Y. Optimization of enzymatic hydrolysis parameters for antioxidant capacity of peptide from goat placenta. Food Bioprod. Process. 2011, 89, 202-208. [CrossRef]

46. Le Man, H.; Behera, S.K.; Park, H.S. Optimization of operational parameters for ethanol production from Korean food waste leachate. Int. J. Environ. Sci. Technol. 2010, 7, 157-164. [CrossRef]

47. Gojun, M.; Pustahija, L.; Jurinjak Tušek, A.; Šalić, A.; Valinger, D.; Zelić, B. Kinetic parameter estimation and mathematical modelling of lipase catalysed biodiesel synthesis in a microreactor. Micromachines 2019, 10, 759. [CrossRef]

48. Xu, P.; Zheng, G.-W.; Zong, M.-H.; Li, N.; Lou, W.Y. Recent progress on deep eutectic solvents in biocatalysis. Bioresour. Bioprocess 2017, 4, 1-18. [CrossRef]

49. Saleh, J.; Dubé, M.A.; Tremblay, A.Y. Separation of glycerol from FAME using ceramic membranes. Fuel Process. Technol. 2011, 92, 1305-1310. [CrossRef]

50. Tajziehchi, K.; Sadrameli, S.M. Optimization for free glycerol, diglyceride, and triglyceride reduction in biodiesel using ultrafiltration polymeric membrane: Effect of process parameters. Process Saf. Environ. Prot. 2020, 148, 34-46. [CrossRef] 